\title{
Sediment Filter Device
}

National Cancer Institute

\section{Source}

National Cancer Institute. Sediment Filter Device. NCI Thesaurus. Code C50360.

A filter designed to remove particles from a liquid. 